\title{
A comparison of schedule-induced wheel running in rats, hamsters, gerbils, and guinea pigs
}

\author{
WILSON E. BRYANT, JR. and JOSEPH H. PORTER \\ Virginia Commonwealth University, Richmond, Virginia
}

\begin{abstract}
Rats, hamsters, gerbils, and guinea pigs were tested on a fixed-time 1-min food-reinforcement schedule to compare schedule-induced wheel running across the four species. Four of five gerbils and three of five hamsters developed schedule-induced wheel running, whereas, only one of five rats and one of two guinea pigs displayed schedule-induced wheel running. These preliminary data extend the species generality of adjunctive wheel running, and suggest that it is a more robust phenomenon in gerbils and hamsters than in rats.
\end{abstract}

In 1961, Falk observed that food-deprived rats drink excessive amounts of water while barpressing for food pellets on a variable-interval 1-min (VI 1-min) reinforcement schedule. Falk $(1969,1971,1977)$ has termed this excessive drinking "schedule-induced polydipsia" and classified it as an adjunctive behavior along with other schedule-induced behaviors, such as schedule-induced wheel running (King, 1974; Levitsky \& Collier, 1968; Porter \& Bryant, 1978a; Segal, 1969).

Recently, a great deal of research has been directed toward the species generality of schedule-induced behaviors. Falk (1961) originally observed scheduleinduced polydipsia in rats, but it has also been demonstrated in rhesus monkeys (Porter \& Kenshalo, 1974; Schuster \& Woods, 1966), mice (Palfai, Kutscher, \& Symons, 1971), pigeons (Magyar \& Malagodi, 1980; Shanab \& Peterson, 1969), guinea pigs (Porter, Sozer, \& Moeschl, 1977), gerbils (Porter \& Bryant, 1978a, 1978b), and humans (Fallon, Allen, \& Butler, 1979; Porter, Brown, \& Goldsmith, 1982). The species generality of schedule-induced wheel running has not been studied as extensively as schedule-induced polydipsia, however. With the exception of one study, scheduleinduced wheel running has been studied only in rats. Porter and Bryant (1978a) observed an increase in wheel running in three of four Mongolian gerbils when they were tested on a FT 1-min food schedule (as compared with massed-feeding baseline conditions). The present study was a preliminary attempt to explore the species generality or limitations of schedule-induced wheel running by comparing rats, hamsters, gerbils, and guinea pigs on a FT 1-min food-reinforcement schedule.

This experiment represents a portion of a master's thesis by W. E. Bryant, Jr. The authors would like to thank Gerald C. Llewellyn for supplying the gerbils. Reprint requests should be sent to Joseph H. Porter, Department of Psychology, Virginia Commonwealth University, Richmond, Virginia 23284.

\section{METHOD}

\section{Animals}

Five albino Sprague-Dawley rats [Rattus norvegicus, 4 males and 1 female (R-10)] with mean body weight of $430.6 \mathrm{~g}$, five golden hamsters (Mesocricetus auratus, all males) with mean body weight of $119.5 \mathrm{~g}$, five Mongolian gerbils (Meriones unguiculatus, all males) with mean body weight of $96.4 \mathrm{~g}$, and two albino guinea pigs of the Hartley strain (Cavia Porcellus, both males) with mean body weight of $336.3 \mathrm{~g}$ served in this study. The animals were housed individually in an animal colony room (7-a.m.-light/6-p.m.-dark cycle) and were maintained at $85 \%$ of their free feeding weights by restricting their daily rations of food. Purina rat chow was provided for the gerbils, hamsters, and rats, and Purina guinea pig chow was provided for the guinea pigs as home-cage food. All of the animals' diets were supplemented with liquid vitamin $C(1.0 \mathrm{ml}$ liquid vitamin $C$ to $250 \mathrm{ml}$ $\mathrm{H}_{2} \mathrm{O}$ ) by adding the liquid vitamin $\mathrm{C}$ to the home-cage water. This was done because guinea pigs are incapable of synthesizing vitamin C (Rosenberg, 1942).

\section{Apparatus}

The test chamber was a modified Scientific Prototype operant conditioning chamber (Model A-100) mounted on a standard 14-in.-diam (35.7-cm-diam) Wahmaan Company activity wheel (Model LC-34). The center of the opening $(7 \times 9 \mathrm{~cm})$ to the running wheel was $20 \mathrm{~cm}$ from and to the left of the intelligence panel. The food tray was centered on the intelligence panel $1 \mathrm{~cm}$ above the grid floor. A microswitch mounted on the running wheel provided electromechanical recording of wheel revolutions. Temporal records of wheel running were made on a Ralph Gerbrands Company cumulative recorder (Model C-3). The test chamber was housed in a sound-attenuated chamber provided with a 28-V dc houselight and white masking noise. Standard electromechanical recording and programming equipment was located outside the experiment room. Standard-formula $45-\mathrm{mg}$ Noyes pellets served as reinforcers during test sessions.

\section{Procedure}

Initially, free-feeding body weights were measured on all animals for 3 days. After this period, $85 \%$ body weights were calculated and the animals' body weights were gradually reduced over a period of 3 to 8 days until $85 \%$ body weights were attained. The animals were maintained at $85 \%$ body weights for the remainder of the study by adjustment of their daily rations of food in the home cages. Testing began with 5 days of a massed-feeding baseline condition (Baseline 1), in which the animals had access to the running wheel for $30-\mathrm{min}$ and 30 
food pellets were placed in the food tray at the beginning of the test session. During the next phase of testing, the animals were placed on a FT 1-min schedule, receiving one food pellet every minute, independently of the animals' behavior, until a total of 30 food pellets had been delivered. During the FT-schedule condition, the number of days of testing was variable for the four species. Each species was tested on the FT schedule until the running behavior of that species appeared to be relatively stable, although a minimum of 15 sessions was imposed on all groups. The rats, hamsters, gerbils, and guinea pigs were given $15,22,15$, and 17 test sessions, respectively. During the final phase of testing, massed-feeding baseline conditions were reinstated. The rats, hamsters, gerbils, and guinea pigs were given $5,5,11$, and 6 sessions, respectively, on this final massedfeeding baseline condition (Baseline 2). Once again, testing was conducted until running appeared relatively stable (a minimum of 5 sessions).

\section{RESULTS}

Table 1 shows the mean number of wheel revolutions per session for the last 3 days of each testing condition for the rats, hamsters, gerbils, and guinea pigs. Because of the small number of subjects tested for each species, only a descriptive analysis of the data is presented. Three of the five rats (R-6, R-7, and R-10) showed an increase in running when switched from the first massed-feeding baseline (Baseline 1) to the FT 1-min condition. However, only R-6 showed a subsequent decrease in running when massed-feeding conditions were reinstated (Baseline 2). R-8 and R-9 did not show a reliable increase in wheel running when placed on the FT 1-min schedule. Of the five rats tested, three (R-7, R-9, and R-10) displayed their highest level of running during Baseline 2.

All five of the hamsters increased their running when the FT 1-min schedule was introduced. H-6, H-7, and H-9 showed substantial increases in running, whereas, $\mathrm{H}-8$ and $\mathrm{H}-10$ displayed only a slight increase. All five hamsters displayed a reduction in running when the massed-feeding condition was reinstated in Baseline 2.

All five gerbils displayed substantial increases in wheel running when food pellets were delivered according to the FT 1-min schedule. When the massed-feeding baseline was reinstated, all the gerbils, except for G-8, showed decreased levels of running.

Table 1

Mean Wheel Revolutions per Session and Mean Number of Running Bouts for the Last 3 Days of Each Testing Condition for Each Animal

\begin{tabular}{|c|c|c|c|c|c|c|}
\hline & \multicolumn{2}{|c|}{ Baseline 1} & \multicolumn{2}{|c|}{ FT 1-min } & \multicolumn{2}{|c|}{ Baseline 2} \\
\hline & $\begin{array}{c}\text { Wheel } \\
\text { Revolutions }\end{array}$ & $\begin{array}{c}\text { Running } \\
\text { Bouts }\end{array}$ & $\begin{array}{c}\text { Wheel } \\
\text { Revolutions }\end{array}$ & $\begin{array}{l}\text { Running } \\
\text { Bouts }\end{array}$ & $\begin{array}{c}\text { Wheel } \\
\text { Revolutions }\end{array}$ & $\begin{array}{c}\text { Running } \\
\text { Bouts }\end{array}$ \\
\hline \multicolumn{7}{|c|}{ Rats } \\
\hline $\begin{array}{l}R-6 \\
R-7 \\
R-8 \\
R-9 \\
R-10\end{array}$ & $\begin{array}{l}39.0 \\
10.3 \\
59.0 \\
13.0 \\
80.6\end{array}$ & $\begin{array}{r}9.3 \\
3.0 \\
13.6 \\
4.6 \\
13.6\end{array}$ & $\begin{array}{r}75.6 \\
30.6 \\
62.6 \\
18.0 \\
292.0\end{array}$ & $\begin{array}{r}16.3 \\
7.6 \\
15.6 \\
5.3 \\
25.3\end{array}$ & $\begin{array}{r}36.3 \\
35.6 \\
48.6 \\
35.3 \\
381.6\end{array}$ & $\begin{array}{r}10.6 \\
5.0 \\
11.6 \\
9.3 \\
27.3\end{array}$ \\
\hline $\begin{array}{l}\text { Mean } \\
\text { SeM }\end{array}$ & $\begin{array}{l}40.4 \\
13.4\end{array}$ & $\begin{array}{l}8.8 \\
2.2\end{array}$ & $\begin{array}{l}95.8 \\
50.2\end{array}$ & $\begin{array}{r}14.0 \\
3.6\end{array}$ & $\begin{array}{r}107.5 \\
68.6\end{array}$ & $\begin{array}{r}12.8 \\
3.8\end{array}$ \\
\hline \multicolumn{7}{|c|}{ Hamsters } \\
\hline $\begin{array}{l}\text { H-6 } \\
\text { H-7 } \\
\text { H-8 } \\
\text { H-9 } \\
\text { H-10 }\end{array}$ & $\begin{array}{r}551.3 \\
383.7 \\
339.0 \\
461.3 \\
1011.0\end{array}$ & $\begin{array}{l}17.0 \\
27.3 \\
22.3 \\
25.3 \\
29.7\end{array}$ & $\begin{array}{r}1051.3 \\
823.3 \\
351.3 \\
723.0 \\
1108.7\end{array}$ & $\begin{array}{l}27.3 \\
26.3 \\
20.3 \\
25.0 \\
29.0\end{array}$ & $\begin{array}{l}826.0 \\
386.3 \\
143.0 \\
178.0 \\
905.0\end{array}$ & $\begin{array}{l}25.3 \\
17.7 \\
12.0 \\
15.0 \\
25.3\end{array}$ \\
\hline $\begin{array}{l}\text { Mean } \\
\text { SeM }\end{array}$ & $\begin{array}{l}549.3 \\
120.9\end{array}$ & $\begin{array}{r}23.9 \\
2.2\end{array}$ & $\begin{array}{l}811.5 \\
135.2\end{array}$ & $\begin{array}{r}25.6 \\
1.5\end{array}$ & $\begin{array}{l}487.7 \\
160.2\end{array}$ & $\begin{array}{r}19.1 \\
2.7\end{array}$ \\
\hline $\begin{array}{l}\text { G-6 } \\
\text { G-7 } \\
\text { G-8 } \\
\text { G-9 } \\
\text { G-10 }\end{array}$ & $\begin{array}{l}502.0 \\
168.7 \\
201.7 \\
303.3 \\
265.0\end{array}$ & $\begin{array}{l}25.6 \\
19.6 \\
21.3 \\
26.3 \\
26.0\end{array}$ & $\begin{array}{r}\text { Gerbils } \\
1109.7 \\
559.7 \\
315.7 \\
726.0 \\
558.0\end{array}$ & $\begin{array}{l}30.0 \\
29.3 \\
27.6 \\
30.0 \\
30.0\end{array}$ & $\begin{array}{l}969.7 \\
488.7 \\
361.3 \\
397.7 \\
327.7\end{array}$ & $\begin{array}{l}28.0 \\
26.6 \\
23.3 \\
26.3 \\
25.6\end{array}$ \\
\hline $\begin{array}{l}\text { Mean } \\
\text { SeM }\end{array}$ & $\begin{array}{r}288.1 \\
58.4\end{array}$ & $\begin{array}{r}23.8 \\
1.4\end{array}$ & $\begin{array}{l}653.8 \\
131.4\end{array}$ & $\begin{array}{r}29.4 \\
0.5\end{array}$ & $\begin{array}{l}509.0 \\
227.6\end{array}$ & $\begin{array}{r}26.0 \\
0.8\end{array}$ \\
\hline \multicolumn{7}{|c|}{ Guinea Pigs } \\
\hline $\begin{array}{l}\text { GP-7 } \\
\text { GP-8 }\end{array}$ & $\begin{array}{l}60.7 \\
84.0\end{array}$ & $\begin{array}{r}8.7 \\
11.7\end{array}$ & $\begin{array}{l}256.3 \\
208.7\end{array}$ & $\begin{array}{l}20.0 \\
17.7\end{array}$ & $\begin{array}{l}376.0 \\
153.7\end{array}$ & $\begin{array}{l}24.3 \\
20.7\end{array}$ \\
\hline $\begin{array}{l}\text { Mean } \\
\text { SeM }\end{array}$ & $\begin{array}{l}72.4 \\
11.6\end{array}$ & $\begin{array}{r}10.2 \\
1.5\end{array}$ & $\begin{array}{r}232.5 \\
23.8\end{array}$ & $\begin{array}{r}18.8 \\
1.2\end{array}$ & $\begin{array}{l}264.8 \\
111.2\end{array}$ & $\begin{array}{r}22.5 \\
1.8\end{array}$ \\
\hline
\end{tabular}

Note-SeM = standard error of the mean. 
Both guinea pigs increased their running when the FT 1-min schedule was in effect, but only GP-8 showed a subsequent decrease when returned to the massedfeeding condition.

Table 1 also shows the mean number of running bouts for each species. A running bout was defined as an interval in which any running occurred. These data were determined from cumulative records. Inspection of the data shows that the rats and guinea pigs consistently ran in fewer intervals than did the hamsters and gerbils. This agrees with the wheel-revolution data. Thus both measures showed that the hamsters and gerbils ran more than the rats and guinea pigs under all testing conditions.

The same three rats (R-6, R-7, and R-10) that showed an increased number of wheel revolutions on the FT 1-min schedule also showed an increased number of running bouts. Only R-6 and R- 8 showed any decrease in running bouts during the second massed-feeding baseline. While both guinea pigs increased the number of running bouts when the FT 1-min food schedule was put into effect, both showed further increases upon return to the massed-feeding condition. Thus, even though GP-8 displayed an increase and then subsequent decrease in the mean number of wheel revolutions, the mean number of running bouts continued to increase across all three testing conditions.

For the hamsters, running occurred in most of the intervals during both baseline and FT 1-min schedule conditions. Only H-6 and H-9 showed any increase from Baseline 1 to FT 1 -min, and it was only a very small increase for H-9. All five hamsters displayed decreases in the number of running bouts during Baseline 2 as compared with FT 1-min. All five gerbils displayed increases in running bouts when the FT 1-min food schedule was in effect, and very slight decreases upon return to Baseline 2.

In Figure 1, sample cumulative records are shown for one animal from each species. The animal selected for each species was the one showing the largest increase and subsequent decrease in wheel revolutions across the three schedule conditions. The hamsters and gerbils displayed similar patterns of running, which were characterized by running throughout the entire interpellet interval. On the other hand, R-6 and GP-8 displayed a pattern more similar to that seen with scheduleinduced polydipsia; that is, most of the running occurred during the postpellet portion of the interval.

\section{DISCUSSION}

If an increase in wheelrunning from the massed-feeding baseline (A) to the FT 1-min food schedule(B) and a subsequent decrease upon return to baseline (A) is used as a criterion, the following animals could be considered to have shown scheduleinduced wheel running (using wheel revolutions as the dependent measure): R-6, H-6, H-7, H-9, H-10, G-6, G-7, G-9, G-10, and GP-8. Thus, 10 of the 17 animals tested could be characterized as having displayed schedule-induced wheel running when the
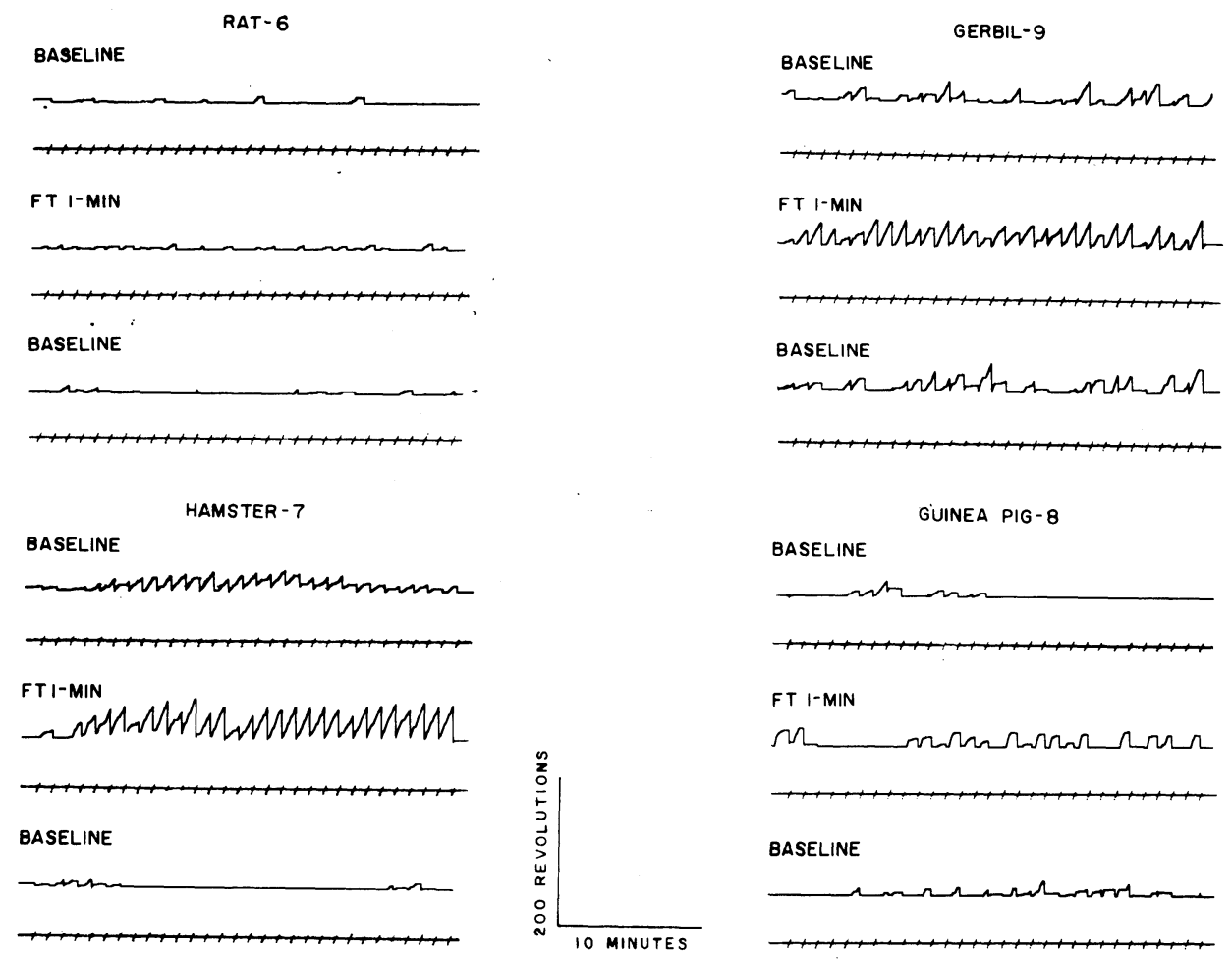

Figure 1. Sample cumulative records are shown for one animal from each species. Wheel revolutions advanced the response pen, and pellet deliveries are indicated by the hatch marks on the event pen. The response pen was reset to baseline with each pellet delivery. 
entire ABA design is considered. However, there was a clear distinction between the four species. Three hamsters and four gerbils tested in this study displayed schedule-induced wheel running under the same schedule parameters utilized for scheduleinduced polydipsia testing in our laboratory with rats. The pattern of running observed in these animals was similar to patterns previously reported for rats (Levitsky \& Collier, 1968) and gerbils (Porter \& Bryant, 1978a) in that the animals ran throughout most of the interpellet interval.

The one rat and one guinea pig that displayed scheduleinduced wheel running confined most of their running to the postpellet portion of the interval, with running decreasing in the later portion. This pattern more closely resembles the pattern of drinking usually seen with schedule-induced polydipsia and differs from the pattern of running observed with the hamsters and gerbils in the present study. However, other studies (King, 1974; Levitsky \& Collier, 1968; Penny \& Schull, 1977; Staddon \& Ayres, 1975) and observations in our laboratory (McDonough, Porter, Gitzen, \& Martin, Note 1; Porter, McDonough, Croasdale, $\&$ Schuetze, Note 2) have shown that rats typically do not display a postpellet pattern where running is confined only to the first portion of the interpellet interval. Rather, running tends to be distributed throughout the entire interval. We (McDonough et al., Note 1; Porter et al., Note 2) have, however, observed a schedule modulation of the running pattern in rats which resembles an inverted-U function. Generally, running will peak during the second $15-\mathrm{sec}$ portion of a 1 -min interpellet interval, or during the second $30-\mathrm{sec}$ portion of a 2 -min interpellet interval. Similar patterns of running have also been reported by Peele, Delamater, and Riley (Note 3). Unfortunately, information concerning the pattern of running in hamsters and gerbils in the present study was available only from cumulative records (see Figure 1), and these records do not provide enough detail to determine whether or not a schedule modulation of running similar to that seen with rats occurs with gerbils and hamsters.

Penny and Schull (1977) and Wetherington, Brownstein, and Schull (1977) have argued that wheel-running behavior in rats is neither schedule-induced nor food bound. They found that running during intermittent food schedules, unlike polydipsia, was not excessive in comparison with that in baseline conditions. The results of previous work in our laboratory (McDonough et al., Note 1; Porter etal., Note 2) and of the present study support this conclusion for the running behavior in rats. Also, the running is not usually restricted to the postpellet portion of the interval, as polydipsia is, but tends to be distributed throughout the entire interval. Staddon (1977) has suggested that wheel-running behavior in rats during intermittent reinforcement schedules should be classified as a "facultative" behavior rather than as an adjunctive behavior. Staddon has defined facultative behaviors as those that are not schedule induced (which he calls interim behaviors) and that are not instrumental responses in anticipation of the food (he calls those terminal behaviors). In light of the differences between wheel running and polydipsia in rats and the results of the present study, which seem to suggest that hamsters and gerbils do display schedule-induced wheel running (at least in terms of the criterion of excessiveness), it seems somewhat premature to conclude that schedule-induced polydipsia and running either do or do not belong to a single class of behaviors termed adjunctive.

\section{REFERENCE NOTES}

1. McDonough, J. J., Porter, J. H., Gitzen, J. F., \& Martin, J. C. Wheel running in rats is suppressed, not induced, by intermittent food reinforcement schedules. Paper presented at the meeting of the Southeastern Psychological Association. New Orleans, March 1982.

2. Porter, J. H., McDonough, J. J., Croasdale, P. J., \& Schuetze, M. C. Effects of food deprivation and interreinforce- ment interval on wheel running behavior in rats. Paper presented at the meeting of the Southeastern Psychological Association, New Orleans, March 1982.

3. Peele, D. B., Delamater, A. R., \& Riley, A. L. Scheduleinduced behaviors: An analysis of wheel running. Paper presented at the meetings of the Americal Psychological Association, Washington, D. C., August 1982.

\section{REFERENCES}

FALK, J. L. Production of polydipsia in normal rats by an intermittent food schedule. Science, 1961, 133, 195-196.

F ALK, J. L. Conditions producing psychogenic polydipsia in animals. Annals of the New York Academy of Sciences, 1969, 157, 569-589.

FALK, J. L. The nature and determinants of adjunctive behavior. Physiology \& Behavior, 1971, 6, 577-588.

FALK, J. L. The origin and functions of adjunctive behavior. $A n$ imal Learning \& Behavior, 1977, 5, 325-334.

Fallon, J. H., Allen, J. D., \& Butler, J. A. Assessment of adjunctive behaviors in humans using a stringent control procedure. Physiology \& Behavior, 1972, 22, 1089-1092.

KING, G. D. Wheel running in the rat induced by a fixed-time presentation of water. Animal Learning \& Behavior, 1974, 2, 325-328.

Levitsky, D., \& Collier, G. Schedule-induced wheel running. Physiology \& Behavior, 1968, 3, 571-573.

Magyar, R. L., \& Malagodi, E. F. Measurement and development of schedule-induced drinking in pigeons. Physiology \& Behavior, 1980, 25, 245-251.

Palfai, T., Kutscher, C. L., \& Symons, J. P. Schedule-induced polydipsia in the mouse. Physiology \& Behavior, 1971, 6, 461-462.

Penny, J., \& Schull, J. Functional differentiation of adjunctive drinking and wheel running in rats. Animal Learning \& Behavior, 1977, 5, 272-280.

Porter, J. H., Brown, R. T., \& Goldsmith, P. A. Adjunctive behavior in children on fixed-interval reinforcement schedules. Physiology \& Behavior, 1982, 28, 609-612.

Porter, J. H., \& Bryant, W. E., Jr. Adjunctive behavior in the Mongolian gerbil. Physiology \& Behavior, 1978, 21, 151-155. (a)

Porter, J. H., \& Bryant, W. E., Jr. Acquisition of scheduleinduced polydipsia in the Mongolian gerbil. Physiology \& Behavior, 1978, 21, 825-827. (b)

Porter, J. H., \& Kenshalo, D. R., JR. Schedule-induced drinking following omission of reinforcement in the rhesus monkey. Physiology \& Behavior, 1974, 12, 1075-1077.

Porter, J. H., Sozer, N. N., \& Moeschl, T. P. Scheduleinduced polydipsia in the guinea pig. Physiology \& Behavior, 1977, 19, 573-575.

Rosenberg, H. R. Chemistry and physiology of the vitamins. New York: Interscience, 1942.

Schuster, C. R., \& Woods, J. H. Schedule-induced polydipsia in the rhesus monkey. Psychological Reports, 1966, 19, 823-828.

Segal, E. F. The interaction of psychogenic polydipsia with wheel running in rats. Psychonomic Science, 1969, 14, 141-144.

Shanab, M. E., \& Peterson, J. L. Polydipsia in the pigeon. Psychonomic Science, 1969, 15, 51-52.

Staddon, J. E. R. Schedule-induced behavior. In W. K. Honig \& J. E. R. Staddon (Eds.), Handbook of operant behavior. Englewood Cliffs, N.J: Prentice-Hall, 1977.

Staddon, J. E. R., \& Ayres, S. Sequential and temporal properties of behavior induced by a schedule of periodic food delivery. Behavior, 1975, 54, 26-49.

Wetherington, C. L., Brownstein, A. J., \& Shull, R. L. Schedule-induced running and chamber size. Psychological Record, 1977, 27, 703-713.

(Manuscript received for publication May 9, 1983.) 